Журнал«Герспективитаінновації науки

(Серія «Гедагогіка», Серія «Гиихологія», Серія «Медицина»

№5(5) 2021

УДК 378.018

https://doi.org/10.52058/2786-4952 -2021-5(5)-614-626

Файермен Олена Олександрівна аспірантка кафедри інноваційних технологій з педагогіки, психології та соціальної роботи, ВНЗ «Університет імені Альфреда Нобеля», вул. Січеславська Набережна, 18, м. Дніпро, 49000, тел.: (0800) 75-51-57, e-mail: olenafayerman@yahoo.com,npvolkova@yahoo.com, https://orcid.org/0000-0003-2487-4063

\title{
КОМПОНЕНТНО-СТРУКТУРНИЙ АНАЛІЗ ФЕНОМЕНА «ГОТОВНІСТЬ МАЙБУТНІХ ФАХІВЦІВ СОЦІОНОМІЧНОЇ СФЕРИ ДО СОЦІАЛЬНОЇ ПІДТРИМКИ БАТЬКІВ ДІТЕЙ 3 ОСОБЛИВИМИ ПОТРЕБАМИ»
}

Анотація. У статті презентовано авторський підхід до компонентноструктурного складу феномена «готовність майбутніх фахівців соціономічної сфери до соціальної підтримки батьків дітей 3 особливими потребами». На підставі аналізу наукових розвідок обгрунтовано такі структурні складові готовності майбутніх фахівців соціономічної сфери до соціальної підтримки батьків дітей 3 особливими потребами: ціннісно-мотиваційний, змістовнотеоретичний, операційно-практичний, особистісний. Ціннісно-мотиваційний компонент представлено мотиваційно-спрямувальним критерієм та такими показниками: рівень потреби у досягненні (прагнення до успіху, саморозвитку, самовдосконалення), спрямованості на взаємодію, особистісних цінностей (цінність «сміливість», «гуманність», «справедливість», «помірність». Змістово-теоретичний компонент виявляється за когнітивним критерієм, який визначається такими показниками: рівень прагнення до здобування знань та їх застосування у професійній діяльності, допитливості, відкритості новому досвіду; повнота, міцність і характер засвоєння знань щодо соціальної підтримки сімей із дітьми з особливими потребами). Операційно-практичний складник представлено діяльнісним критерієм, основу якого становить сукупність проєктувальних, конструктивних, організаторських, мовленнєвих, інтерактивних, морально-етичних умінь. Особистісний компонент аналізується за особистісним критерієм та показниками: рівень сформованості соціального інтелекту, толерантності, емпатії, рефлексії. Розкрито зміст компонентів готовності майбутніх фахівців соціономічної сфери до соціальної підтримки батьків дітей з особливими потребами

Ключові слова: соціальна підтримка, батьки дітей 3 особливими потребами, готовність майбутніх фахівців соціономічної сфери до соціальної підтримки батьків дітей 3 особливими потребами, ціннісно-мотиваційний, змістово-теоретичний, операційно-практичний, операційно-практичний компоненти. 
Fayerman Olena Oleksandrivna Graduate student of the Department of the Innovative Technologies in Psychology, Pedagogy, and Social Work Department, Alfred Nobel University, Sicheslavska Naberezhna St., 18, Dnipro, 49008, tel.: (0800) 75-51-57, e-mail: olenafayerman@yahoo.com, npvolkova@yahoo.com, https://orcid.org/0000-0003-2487-4063

\title{
COMPONENT AND STRUCTURAL ANALYSIS OF THE PHENOMENON OF THE READINESS OF FUTURE SOCIONOMIC SPECIALISTS TO PROVIDE SOCIAL SUPPORT TO THE PARENTS OF CHILDREN WITH SPECIAL NEEDS
}

\begin{abstract}
The article presents the author's approach to the component-structural composition of the phenomenon of the readiness of future specialists in the sociological field to provide social support to the parents of children with special needs. Based on the analysis of scientific research, the following structural components as value and motivation, content and theoretical, operational and practical, personal components are substantiated. Value and motivation interaction component is represented by motivational-oriented criteria and such indicators as the level of need to achieve including striving for success, self-development, selfimprovement, and personal values, the value of "humanity", the value of "justice", the value of "moderation". The content and theoretical component is detected by a cognitive criterion, which is studied according to the level of desire to gain knowledge for their further application in professional activities, curiosity, new experience openness, compliance, strength, and nature of the acquisition of knowledge on social support for families with children with special need. The operational and practical component is characterized by activity criterion, the basis of which is a set of design, constructive, organizational, speech, interactive, moral and ethical skills. The personal component is analyzed due to the level of formation of social intelligence, tolerance, empathy, reflection. The content of the components of the readiness of future social workers to provide social support to children with special needs is revealed.
\end{abstract}

Keywords: social support, parents of children with special needs, readiness of future specialists in the sociological field to provide social support to the parents of children with special needs, children with special needs, value and motivation, content and theoretical, operational and practical, personal components.

Постановка проблеми. Входження України до $Є C$ передбачає упровадження європейських стандартів до забезпечення прав дитини i соціальної підтримки вразливих сімей, зокрема сімей, які виховують дітей 3 особливими потребами, тобто дітей, чиї потреби виходять за межі загальноприйнятих норм. Поява у родині дитини з особливими потребами, як правило, спричинює не тільки сильні переживання у ії членів (відчуття кризи, стресу, депресії, втрати смислу життя, самотності та виокремленості тощо, 
пов’язані 3 невизначеністю соціального статусу дитини), але й змінює функціонування сім’ї як соціальної системи, появу соціальних труднощів у сімейному вихованні, виникнення або загострення сімейних проблем, деформацію міжособистісних стосунків між членами сім’ї, порушення їх соціальних зв’язків тощо. Зрозуміло, що такі родини потребують соціальної підтримки 3 боку фахівців соціономічної сфери (психологи, соціальні працівники, соціальні педагоги), надання ними комплексу соціальних послуг, реалізація яких дозволить покращити якість життя сімей. Зазначене актуалізує питання щодо формування готовності майбутніх фахівців соціономічної сфери до соціальної підтримки батьків дітей з особливими потребами, що передбачає визначення структури даного поняття.

Аналіз останніх досліджень і публікацій. Проблеми підтримки сімей, які виховують дитину з особливими потребами за останні роки привернули увагу та були розглянуті низкою вітчизняних вчених (О. Безпалько, Л. Кобилянська, I. Козубовська, Н. Майструк, I. Макаренко, Л. Оліференко, О. Пюра, I. Трубавіна, 3. Удич, Т. Чечко та ін.). Щодо формування готовності майбутніх фахівців соціономічної сфери до роботи в інклюзивному просторі, то дані питання розглядаються М. Буйняк, О. Гноєвською, О. Денисюк, С. Сфімовою, Т. Логвиненко, І. Малишевською, А. Шульгою та ін. Незважаючи на знгачну кількість досліджень, вважаємо, що питання готовності майбутніх фахівців соціономічної сфери до соціальної підтримки батьків дітей 3 особливими потребами залишається пріоритетним для дослідників, тому потребує подальшого вивчення.

Мета статті - обгрунтувати компонентно-структурний склад феномена «готовність майбутніх фахівців соціономічної сфери до соціальної підтримки батьків дітей з особливими потребами».

Виклад основного матеріалу. Аналіз наукових розвідок показав, що дослідженню сутності й структури готовності до професійної діяльності фахівців соціономічної сфери присвячено роботи Т. Голубенко [1], К. Сгорової [2], I. Калиновська [3], О. Карпенко [4], О. Повідайчик [5] та ін. Так, дослідники мають різні погляди на структуру досліджуваної готовності, виокремлюючи такі компоненти: мотиваційно-особистісний, змістовий, операційно-дієвий (Т. Голубенко), мотиваційний, теоретичний, практичний i рефлексивний (К. Сгорова), світоглядний, змістовий, операційний (О. Карпенко), мотиваційно-ціннісний, когнітивний, діяльнісний та емоційно-вольовий компоненти (О. Повідайчик); мотиваційно-ціннісний, пізнавально-когнітивний, операційно-діяльнісний (І. Калиновська).

Отже, грунтуючись на результатах аналізу вищезазначених наукових джерел, напрями соціальної підтримки батьків дітей з особливими потребами, яку здійснюють фахівців соціальної сфери (психологи, соціальні працівники, соціальні педагоги), іхні спеціальні (фахові, предметні) компетентності згідно iз стандартами вищої освіти за спеціальностями 231 «Соціальна робота», 053 «Психологія» для другого магістерського рівня вищої освіти, виокремлюємо 
такі компоненти структури готовності майбутніх фахівців соціономічної сфери до соціальної підтримки батьків дітей з особливими потребами, критерії для кожного компонента та показники таких критеріїв.

Ціннісно-мотиваційний компонент. Шлях до ефективної організації процесу майбутніх фахівців соціономічної сфери до соціальної підтримки сімей із дітьми з особливими потребами лежить через розуміння мотивів їх діяльності, ціннісних орієнтацій і смислових установок фахівця. Лише чітко усвідомлюючи, що $є$ рушієм діяльності фахівця соціономічної сфери, що стимулює його, які мотиви лежать в основі його дій, можна націлитися на розроблення ефективної системи впливу на процес формування його готовності до здійснення професійної діяльності, зокрема соціальної підтримки сімей із дітьми з особливими потребами.

О. Леонтьєв [6] наголошує, що одні мотиви, спонукуючи до діяльності, надають їй особистісного смислу (смислотворчі) і певної спрямованості, інші відіграють роль спонукальних чинників. Саме розподіл функцій смислотворення і спонукання між мотивами однієї діяльності дає змогу зрозуміти головні взаємозв'язки, які характеризують мотиваційну сферу особистості, тобто побачити ієрархію мотивів в діяльності

Мотивачія досягнення (фр. motif - причина, що спонукає, лат. movere рухати) - один із різновидів мотивації діяльності, яка пов'язана з потребами індивіда досягати успіхів і уникати невдач [7, с. 25]. Мотивацію досягнення як один 3 найпотужніших рушіїв поведінки людини, форму прояву потреби особистості в досягненнях, а отже покращенні результатів власної професійної діяльності, вдосконаленні компетентностей; к стійке прагнення зробити щось швидко i добре, досягти певного рівня в будь-якій справі, розглядали, Дж. Аткінсон, Д. Мак-Клелланд, Л. Грень, М. Далгатов, В. Стасюк, Х. Хекхаузен та ін.

Так, В. Стасюк зазначає, що мотивація досягнень $\epsilon$,рушієм розвитку людини, тим чинником, що зумовлює прагнення особистості розвиватися $\mathrm{i}$ вдосконалювати себе, свої вміння і навички" [8, с. 149]; вона стимулює фахівця на досягнення позитивного результату, $\epsilon$ важливим засобом реалізації професійних цілей.

Д. Мак-Клелланд виокремив особливості, притаманні людям з високим рівнем розвитку „мотиву на досягнення": несхильність надмірно ризикувати, вміння ставити перед собою виважені, помірковані цілі; надання переваги таким ситуаціям, коли відповідальність за їх подолання лежить особисто на них, а успіх при цьому залежить, переважно, від особистих зусиль і здібностей; погляд на результат як засіб, на підставі якого можна коригувати поведінку з метою надання ій більшої ефективності і досягнення більш високих результатів [9]. Отже, люди, мотивовані на успіх, ставлять перед собою позитивну мету, досягнення якої розглядатиметься ними як успіх; прагнуть до підвищення рівня своїх можливостей. Для них властиве очікування успіху, вони впевнені в ньому. Робота у них викликає позитивні емоції. Щодо майбутніх фахівців, то на 
здійснення студентами 3 високим рівнем мотивації досягнення навчальної діяльності впливає система внутрішніх мотивів, що забезпечує ефективне оволодіння майбутнім фахом.

Для розвитку мотивації досягнення для майбутніх фахівців соціономічної сфери доцільним $є$ створення розвиваючого освітнього середовища 3 використанням інноваційних методів навчання, залучення їх проєктної, дослідницької діяльності, що сприятиме усвідомленню цінності знань і практичних навичок для успішного оволодіння майбутньою професійною діяльністю, заохочуватиме до самоосвіти як у професійному, так $\mathrm{i}$ в особистісному аспекті.

Зрозуміло, що тлом діяльності соціальної підтримки може бути сформована домінуюча мотивація, яка визначає певний вид спрямованості особистості. Тому важливим показником досліджуваного критерію виокремлюємо спрямованість особистості, яка визначається системою домінуючих мотивів поведінки і діяльності. Л. Божович, С. Рубінштейн та ін. розглядають спрямованість як вищий рівень структури особистості; iі психологічний «стрижень» та інтегруюча основа діяльності, яка закладає систему відносин людини зі світом і до світу, визначає основні лінії поведінки, систему цінностей i поглядів, позицію в житті i світогляд особистості. Спрямованість особистості має вплив на всі сфери діяльності людини, зокрема професійне самовизначення.

Дослідники акцентують увагу на таких їі різновидах: спрямованість на себе (особиста спрямованість) - орієнтація на пряму винагороду й задоволення, агресивність у досягненні статусу, владність, схильність до суперництва, дратівливість, тривожність; спрямованість на спілкування (взаємодію) - прагнення за будь-яких умов підтримувати відносини з людьми, орієнтуватися на спільну діяльність...; орієнтація на соціальне схвалення, залежність від групи, потреба у прихильності й емоційних відносинах із людьми; спрямованість на справу (завдання) - зацікавленість у вирішенні ділових проблем, виконанні роботи якнайкраще, орієнтація на ділове співробітництво, здатність відстоювати в інтересах справи власну думку, яка корисна для досягнення загальної мети.

Вважаємо, що фахівці соціономічної сфери, які здійснюють соціальну підтримку сімей із дітьми з особливими потребами, мають мати сформовану спрямованість на взаємодію та на вирішення поставлених завдань під час співпраці 3 батьками. Інакше розраховувати на ефективність соціальної підтримки неможливо.

Виокремлюючи цей критерій, варто звернутися до наукових здобутків представників позитивної психології у вимірюванні «позитивних» рис характеру.

Стрижнем у підгрунті процесу підготовки майбутніх фахівців соціономічної сфери до соціальної підтримки сімей із дітьми 3 особливими потребами є система ціннісних орієнтацій. Саме вона формує спрямованість 
особистості. Причому кожен учинок, кожна дія фахівця, вибір способів вирішення професійно важливих завдань, професійних і життєвих колізій, шляхів подолання негативних наслідків, певним чином визначені цією системою. Ціннісні орієнтації розглядають як «основні компоненти механізму, що здійснює внутрішню регуляцію такого різновиду соціальної поведінки, як вибір професії» $[10$, с. 27].

Вагомими виявилися погляди представників позитивної психології у вимірюванні «позитивних» рис характеру (character strengths), що розроблені 3 урахуванням загальнолюдських чеснот (virtues) та індивідуально психологічних властивостей (К. Петерсон і М. Селігман) [10]. Розроблений авторами перелік «здорових рис» особистості спирається на опис ментальних (mental) відхилень, що містяться у Діагностичному і статистичному довіднику ментальних розладів, розробленому у США (DSMIV/DR). Ці риси були відібрані як загальнолюдські цінності, серед яких дослідниками було названо такі: мудрість дає уявлення про когнітивні можливості людини, які виявляються в iі активному прогнозуванні до здобування знань та їх застосуванні у житті (креативність, допитливість, відкритість досвіду, любов до навчання, відчуття перспективи); сміливість передбачає виявлення стійкості i життєвої енергії, необхідної для забезпечення активних зусиль людини, спрямованих на досягнення мети при виникненні труднощів i перешкод (хоробрість, наполегливість, цілісність, життєздатність та життєстійкість (vitality); гуманність забезпечує здатність формувати i підтримувати доброзичливі соціальні зв'язки (любов, доброта, соціальний інтелект, готовність і вміння підтримувати доброзичливі стосунки 3 оточуючими); справедливість виявляється у громадянськості та сприянні суспільному благополуччю (громадянськість (citizenship), справедливе ставлення до оточуючих, лідерство); поміркованість - у стриманості, саморегуляції (обачливість (forgiveness and mercy); скромність, стриманість, саморегуляція); трансцендентність - у наявності уявлень про сенс життя і відчуття власного зв'язку iз навколишнім світом (цінування красоти i видатних досягнень; вдячність, надія, гумор, духовність). До кожної з шести цінностей віднесено по 3-5 позитивних властивостей, що були визначені з урахуванням протилежних їм можливих відхилень. Дібрані риси характеризують усі найважливіші ознаки особистості як суб'єкта соціальної підтримки сімей із дітьми 3 особливими потребами, а саме вони відображають функціонування особистості як: суб'єкта пізнання (риси, що згуртовані навколо чесноти «Мудрість») (показник когнітивного критерію); суб'єкта активності (риси, об'єднані навколо чесноти «Сміливість», що характеризують такі властивості особистості, як наполегливість і здатність до подолання життєвих проблем та можливих «викликів» життя); суб 'єкта спілкування $і$ взаємодії (риси, об'єднані навколо чеснот «Гуманність», та «Поміркованість» - любов, доброта, соціальний інтелект); спроможність, обачливість та ін.

Ціннісно-мотиваційний компонент подаємо мотивацุійно-спрямувальним 
Журнал«Герспективитаінновації наукиљ

(Серія «Гедагогіка», Серія«Гцихологія», Серія«Медицина»

№5(5) 2021

критерієм, який визначається такими показниками, як рівень потреби у досягненні (прагнення до успіху, саморозвитку, самовдосконалення), спрямованості на взаємодію, особистісних цінностей (цінність «сміливість» (наполегливість, ентузіазм), цінність «гуманність» (доброзичливість), цінність «справедливість» (об'єктивність та справедливість, громадянськість та кооперація), цінність «помірність» (обачливість, саморегуляція).

Змістово-теоретичний компонент. Відображає обсяг професійно важливих знань майбутніх фахівців соціономічної сфери, що забезпечують ефективну професійну діяльність у напрямі здійснення соціальної підтримки сімей із дітьми 3 особливими потребами, а саме: сутність, зміст, види соціальної підтримки батьків дітей з особливими потребами (психологічна, правова, соціально-економічна, соціально-педагогічна, соціально-медична); моделі соціальних інтервенцій, покликаних забезпечити соціальну підтримку сімей, які виховують дітей 3 особливостями розвитку (екологічна, синергетична, сімейно-зорієнтована, модель подвійної адаптації АВСХ МакКубена); стратегї соціальної підтримки: метод сімейно-зорієнтованої практики, практика формування резілієнсу, он-лайн соціальна підтримка; нормативно-правова база щодо соціальної підтримки; існуючі зарубіжні й вітчизняні практики соціальної підтримки сімей із дітьми 3 особливими потребами; психологічні особливості батьків дітей з особливими потребами; алгоритм соціальної підтримки соціальної підтримки батьків дітей 3 особливими потребами; теорія кризового втручання; технології вивчення потреб та проблем сім’і, яка виховує дитину 3 особливими потребами, технологія ведення випадку; організація роботи команди фахівців, які здійснюють соціальну підтримку сімей із дітьми 3 особливими потребами; індивідуальні та групові (групи самодопомоги та взаємодопомоги, школа батьківської підтримки, тренінги) форми соціальної підтримки, форми підтримки батьків (індивідуальна, колективна, наочна, індивідуальні бесіди та практикуми, консультування, семінари, лекції, соціологічне дослідження, взаємодія з громадськими організаціями) та ін. Вони мають бути обізнаними про те, як доброзичливо і шанобливо побудувати процес взаємодії з батьками, спираючись на їхні сильні сторони, враховуючи їх потреби, як вирішувати разом з батьками проблемні ситуації, формувати у батьків навички самостійної підтримки нових позитивних змін без сторонньої допомоги; пропонувати інформацію батькам / членам сімей для створення домашнього середовища, що стимулює розвиток дитини з особливими потребами.

Крім того вважаємо, що майбутні фахівці соціономічної сфери мають володіти високорозвинутою цінністю «Мудрість», що $є$ показником когнітивних можливостей людини, які виявляються в іï активному прагненні до здобування знань та їх застосування у професійній діяльності, допитливості, відкритості новому досвіду.

Змістово-теоретичний компонент подаємо когнітивним критерієм, який визначається такими показниками, рівень прагнення до здобування знань та їх 
застосування у професійній діяльності, допитливості, відкритості новому досвіду; повнота, міцність і характер засвоєння знань щодо соціальної підтримки сімей із дітьми з особливими потребами.

Операційно-практичний компонент. Основу його становить сукупність умінь фахівця, необхідних для здійснення ефективної соціальної підтримки сімей із дітьми з особливими потребами. На підставі аналізу наукових праць Н. Заверико, 3. Кияниці, I. Трубавіної, Ж. Петрочко, 3. Удич та ін. нами виокремлено такі групи умінь:

- гностичні (збір та інтерпретація інформації з метою вивчення (оцінки) потреб батьків (сімей), які виховують житину з особливими потребами; аналіз особливостей життєдіяльності сімей, які виховують дітей 3 особливими потребами; об'єктивна оцінка соціальних та виховних можливостей сім'і; аналіз труднощів та помилок сімейного виховання, причин та шляхів запобігання; аналіз власної діяльності у роботі з батьками, іiі успіхів та недоліків, та досвіду взаємодії із сім'ями, які виховують дітей з особливими потребами);

- проєктувальні (проектування цілей, завдань роботи з батьками (за результатами оцінки потреб); передбачення, розпізнавання i задоволення запитів батьків; розробка індивідуального плану підтримки батьків із зазначенням соціальних послуг; визначення доцільних форм та методів соціальної підтримки; усвідомлення процедури й результатів соціальної підтримки батьків; допомога батькам моделювати ситуації в процесі взаємодії зі своїми дітьми; допомога батькам бачити і прогнозувати можливості їх саморозвитку, самодопомоги, шляхом мобілізації внутрішніх і зовнішніх ресурсів);

- організаторські (організація консультативної і просвітницької роботи 3 батьками; організація соціального навчання батьків щодо формування відповідального батьківства; залучення наявних фінансових, матеріальних та інших можливостей громади для підтримки батьків; ведення звітів та оцінка результатів соціальної підтримки сім’, що виховує дитину 3 інвалідністю, корекція подальшої роботи; створення умов для продуктивної спільної діяльності і взаємодії з батьками для досягнення загальних цілей; залучення батьків до активної співпраці з різними фахівцями для вирішення проблем; допомога в оформленні запитів до відповідних інстанцій, заяв, документів на отримання усіх видів послуг; посередництво між батьками і психологами, медиками, юристами, іншими спеціалістами);

- мовленнєві (здатність використовувати мовні засоби відповідно до мети й ситуації спілкування; планування та добір доречно поставлених запитань, реплік; володіння оптимальним темпом мовлення, належним використанням пауз та логічних наголосів у повідомленнях; володіння культурою мовлення, яка передбачає змістовність, доречність, точність, логічність і послідовність, правильність і чистоту, різноманітність, виразність мовлення; розуміння невербальних комунікативних сигналів; здатність слухати і розуміти батьків); 
- інтерактивні (добір методів впливу (особистий приклад, пояснення, переконання, прохання, звернення, доказ тощо) на батьків; підтримання зворотного зв'язку під час взаємодії, володіння увагою - внутрішньою, зовнішньою; здійснення самоконтролю, саморегуляції за будь-якої ситуації; коригування чи зміна за необхідності комунікативної поведінки; встановлення контакту із батьками та дитиною 3 особливими по требами, створення атмосфери довіри; попередження і врегулювання конфліктних ситуацій, подолання агресії з мінімальним ризиком для себе та інших; аналіз та адекватне оцінювання власної діяльності у процесі соціального супроводу батьків);

- морально-етичні (дотримання принципів та правил професійної етики; усвідомлення власних моральних помилок i шляхів їх виправлення; встановлення толерантних відносин з батьками; створення терапевтичного клімату; демонстрація соціально відповідальної та свідомої поведінки, слідувати гуманістичним та демократичним цінностям; демонстрація розуміння почуттів іншого; знаходження необхідних для моральної підтримки батьків слів і аргументів).

Сформованість у майбутніх фахівців соціальної сфери зазначених груп умінь сприятиме здійсненню ефективної соціальної підтримки батьків дітей 3 особливими потребами.

Особистісний компонент. Виокремлюючи даних компонент, спиралися на погляди науковців (Л. Буркова, Н. Волкова, Н. Різун, С. Калаур, Ж. Петрочко, В. Корнещук, О. Пришляк та ін.), які акцентували увагу на особистісних якостях фахівців соціономічної сфери, діяльність яких пов'язана iз взаємодією 3 сім'єю, яка виховує дітей 3 особливими потребами: відповідальність за якість роботи з клієнтами, альтруїстичні якості (людяність, уважність, чуйність, доброта, тактовність тощо), толерантність, гнучкість у спілкуванні (системи «фахівець-клієнт», «фахівець-група/групи клієнтів»), емпатія, ентузіазм та оптимізм, віра в можливість ефективної допомоги клієнту, упевненість в собі, наполегливість, здоровий глузд, милосердя, психологічні якості (комунікабельність, адекватна самооцінка, самоконтроль, самокритичність, стресостійкість, спроможність до тривалих психологічних напружень та ін.), високий рівень життєвих домагань, налаштованість на творення добра для клієнтів і надання їм професійної допомоги.

Поділяючи погляди дослідників, акцентуємо увагу на соціальному інтелекті, толерантності, емпатії, рефлексії.

Вважаємо, що соиіальний інтелект є важливою особистісною якістю, яка необхідна фахівцю під час здійснення соціальної підтримки батьків, які виховують дитину з особливими потребами.

Значну увагу вивченню проблеми соціального інтелекту приділяли зарубіжні дослідники. Так, Г. Гарднер (H. Gardner), вивчаючи соціальний інтелект, репрезентував дві його форми: міжособистісний (спроможність людини розуміти інших, усвідомлювати мотиви їх діяльності, ставлення до 
роботи, вдосконалювати співпрацю 3 цими людьми і відповідним чином реагувати на них); внутрішньоособистісний (властивість людини, спрямовану на себе, спроможність формувати точну адекватну модель власного «Я» та використовувати цю модель для ефективного функціонування в житті, здатність людини розуміти власні почуття, їх джерела а відтак регулювати власну поведінку, спираючись на перелічені складники) [11].

Науковці свідомі того, що соціальний інтелект $\epsilon$ провідною якістю фахівців соціономічних професій. Так, за твердженням Я. Каплуненко, А. Федоренко, соціальний інтелект $\epsilon$ «професійно важливою якістю в професіях типу «людина-людина» i деяких професіях типу «людина художній образ» [12, с. 48]; засадничою для фахівців професійного середовища «людина-людина», діяльність яких зосереджена на безпосередній взаємодії 3 іншими людьми [13, с. 38]. Дослідники свідомі того, що рівень розвитку соціального інтелекту багато в чому обумовлює успішність професійної діяльності людей соціономічних професій.

Спираючись на погляди науковців, вважаємо, що соціальний інтелект є складовою готовності майбутніх фахівців соціономічної сфери до соціальної підтримки батьків дітей з особливими потребами. Він дозволяє особистості розпізнавати свої емоції та емоційний стан співрозмовників, розуміти власні емоції та їх вплив на поведінку, усвідомлювати, як емоції впливають на ефективність і здатність приймати рішення; регулювати вираження своїх почуттів i приймати рішення, що стосуються роботи; справлятися 3 негативними емоціями і імпульсами, залишаючись незворушним у стресових ситуаціях тощо.

Сформованість у майбутніх фахівців соціономічних професій толерантності вважаємо передумовою ефективної соціальної підтримки батьків. Наявність даної якості показує, якою мірою психолог, соціальний працівник сприймає суб’єктивно небажані, а інколи й неприйнятні для нього індивідуальні особливості батьків, або інших членів родини, яка виховує дитину 3 особливими потребами (розгубленість, пригніченість, внутрішньоособистісні конфлікти, демонстрація почуття провини, емоційне напруження, несприятливий психологічний клімат у родині тощо). На наш погляд, толерантність можна розглядати як здатність бачити в іншій людині саме іншу - носія інших цінностей, логіки мислення, інших норм поведінки, усвідомлення іï права бути іншою; безумовно, позитивне ставлення до такої несхожості, уміння бачити іншу людину «зсередини»; здатність глянути на світ одночасно з власного погляду та позиції іншої людини.

Eмпатію (походить від грець. частка «є̇v» позначає «в» (спрямоване

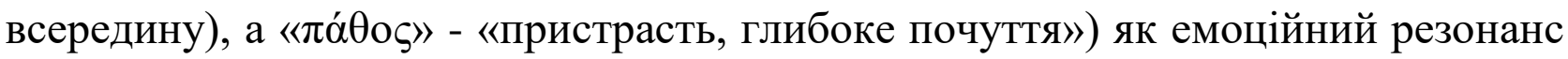
на переживання іншої людини, презентують як відгук людини на почуття і стан іншого; глибоке розуміння однією людиною іншої, таке сприйняття та іï психічного стану, завдяки якому здійснюється осмислення іiі внутрішнього стану проникнення в світ іншої людини. 
Емпатія як механізм формування міжособистісних відносин сприяє їх розвитку і стабілізує, дозволяє надавати підтримку партнерові не тільки в звичайних, але і у важких, екстремальних умовах, коли він особливо іiі потребує. Вона є основою розвитку гуманних відносин, альтруїстичного стилю поведінки, дозволяє відчути переживання інщшої людини та збагнути іiі емоційний стан.

Емпатійне співчуття, співпереживання виступає мотивом-посередником під час надання людині підтримки й допомоги. Упевнені, що майбутні фахівці соціономічної сфери мають бути емпатичними, надавати емоційну відповідь на переживання, думки та почуття об'єкта емпатії, досягнення взаєморозуміння, згоди й прихильності в міжособистісній комунікації фахівця з батьками дітей 3 особливими потребами. Вагомою для нас стала гіпотеза «емпатія - альтруїзм», яку презентував Ч. Батсон: справжня альтруїстична поведінка людини, спрямована на допомогу іншій, не передбачає у відповідь жодної вигоди чи соціального заохочення, зростання поваги чи самоповаги внаслідок надання допомоги, змотивована саме емпатією [14].

Послугування засобами вираження емпатії забезпечує успіх професійної діяльності фахівців соціономічної сфери через реалізацію системи відносин, побудованих не лише на співпереживанні емоційному стану співрозмовника, а на наданні йому дієвої соціальної підтримки.

I нарешті, для здійснення ефективної соціальної підтримки батьків дітей 3 особливими потребами майбутні фахівці соціономічної сфери мають володіти рефлексивністю. Рефлексія (від лат. reflexio - звернення назад, вигин, відображення), осмислення людиною передумов, закономірностей і механізмів власної діяльності, соціального та індивідуального способу існування; самоаналіз [15, с. 211]; міркування, осмислення, самоаналіз своєї діяльності в системі стосунків зі світом, у якому живе особистість.

Необхідність маніфестації рефлексії як складника особистісного критерію досліджуваної готовності обумовлена тим, що взаємодіючи з батьками дитини, яка має особливі потреби, фахівці соціономічної сфери постійно стикаються 3 новими проблемами, ситуаціями, конфліктами, що потребують швидкого та ефективного їх вирішення. Зазначені фахівці мають ставити реальні цілі як основу для оцінки результативності своїх професійних дій; прогнозувати наслідки своїх професійних дій, здійснювати контроль та самоконтроль; адаптувати, доповнювати чи змінювати план, програму, форми та методи роботи відповідно до конкретних умов 3 метою досягнення оптимальних результатів; усвідомлювати виконану діяльність, самокритично ставитись до неї; оцінювати та підводити підсумки досвіду своєї практичної роботи і використовувати у своїй практиці досвід своїх колег; виявляти високу професійну готовність під час виконання своїх обов'язків за будь-яких обставин [15, с. 214]. Отже, рефлексуючий фахівець соціономічної сфери - це особистість, якій притаманні проблемність і критичність мислення, відкритість до діалогу, гнучкість щодо вирішення проблем, варіативність й пластичність у 
діяльності, уміння здійснювати аналіз власного досвіду.

Базуючись на вищенаведених міркуваннях нами виокремлено низький, достатній та високий рівні готовності майбутніх фахівців соціономічної сфери до соціальної підтримки батьків дітей з особливими потребами.

Висновки. Отже, презентований у статті компонентно-структурний аналіз готовності майбутніх фахівців соціономічної сфери до соціальної підтримки батьків дітей з особливими потребами дозволяє конкретизувати зміст даного феномена, більш чітко спрямувати дослідницьку діяльність щодо професійної підготовки майбутніх психологів, соціальних працівників, соціальних педагогів в умовах магістратури.

\section{Лimepamypa:}

1. Голубенко Т.О. Складові готовності майбутніх соціальних працівників до патронажної роботи з людьми похилого віку. Психолого-педагогічні науки. 2012. №5. С. 8-13.

2. Єгорова К. Компоненти готовності майбутніх соціальних працівників до соціальної реабілітації дітей молодшого шкільного віку з дитячим церебральним паралічем. Збірник наукових праць. Педагогічні науки. Херсон, 2017. LXXIX, Том 2. С. 206-209.

3. Калиновська I. С. Підготовка майбутніх практичних психологів до роботи в умовах інклюзивного навчання учнів загальноосвітніх навчальних закладів: дис. ... канд. пед. наук: 13.00.04. Уманський державний педагогічний університет імені Павла Тичини. Умань, 2020. $287 \mathrm{c}$.

4. Карпенко О. Теоретико-методологічні підходи до професійної готовності фахівців соціальної роботи. Науковий часопис НПУ імені М.П. Драгоманова. Соціологія. Соціальна робота. Соціальна педагогіка. Управління. 2009. №11. С. 47-54.

5. Повідайчик О.С. Теорія і практика професійної підготовки майбутніх соціальних працівників до науково-дослідницької діяльності: дис. ... докт. пед. наук: 13.00.04. ДВНЗ «Ужгородський національний університет», Ужгород, 2019.570 с.

6. Леонтьев А. Н. Проблемы развития психики. М. : НПФ «Смысл», 2020. 575 с.

7. Карамушка Л. М. Психологія управління: навч. посібник. К.: Міленіум. 2003. 344 с.

8. Стасюк В.В. Розвиток мотивації досягнення у слухачів як умова ефективності процесу учіння. Вісник Національного університету оборони України. №3(40). 2014. С. 149-154.

9. Mc Clelland D. C., Atkinson J. W., Clark R. A. A scoring manual for the achievement motive. In: Motives in Fantasy, Action and Society, N. Y., 1958. P. 112-148.

10. Peterson C., Seligman M. Character strengths and virtues: A handbook and classification. Washington, DC: American Psychological Association, 2004.

11. Gardner H. Frames of mind: The theory of multiple intelligences. Heinemann : L., 1983. P. 35.

12. Федоренко А. В. Развитие социального интеллекта будущих педагоговпсихологов в процессе адаптации к учебно-профессиональной деятельности : автореф. дисс. ... канд. псих. наук : 19.00.07. Самара, 2013. 24 с.

13. Каплуненко Я. Ю. Особистісні чинники розвитку соціального інтелекту у фахівців соціономічних професій : дис. ...канд. психол. наук : 19.00.01. К., 2016. 262 с.

14. Batson Ch.D. Self-other merging and the empathy-altruism hypothesis: Reply to Neuberg et al. Journal of Personality and Social Psychology. 1997. Vol. 73(3). P. 517 - 522.

15. Супрун Д. М. Теорія та практика професійної підготовки психологів в галузі спеціальної освіти: дис. ... д-ра пед. наук: 13.00.03. Національний педагогічний університет імені М. П. Драгоманова, Київ, 2018. 658 с. 


\section{References:}

1. Holubenko, T.O. (2012). Skladovi hotovnosti maibutnikh sotsialnykh pratsivnykiv do patronazhnoi roboty z liudmy pokhyloho viku [Components of the readiness of future social workers for patronage work with the elderly]. Psykholoho-pedahohichni nauky - Psychological and pedagogical sciences, 5, 8-13 [in Ukrainian].

2. Yehorova, K. (2017). Komponenty hotovnosti maibutnikh sotsialnykh pratsivnykiv do sotsialnoi reabilitatsii ditei molodshoho shkilnoho viku $\mathrm{z}$ dytiachym tserebralnym paralichem [Components of readiness of future social workers for social rehabilitation of children of primary school age with cerebral palsy]. Zbirnyk naukovykh prats. Pedahohichni nauky - Collection of scientific works. Pedagogical sciences, LXXIX, 206-209 [in Ukrainian].

3. Kalynovska, I.S. (2020). Pidhotovka maibutnikh praktychnykh psykholohiv do roboty v umovakh inkliuzyvnoho navchannia uchniv zahalnoosvitnikh navchalnykh zakladiv [Preparation of future practical psychologists to work in the conditions of inclusive education of students of secondary schools]. Candidate's thesis. Uman [in Ukrainian].

4. Karpenko, O. (2009). Teoretyko-metodolohichni pidkhody do profesiinoi hotovnosti fakhivtsiv sotsialnoi roboty [Theoretical and methodological approaches to the professional readiness of social workers]. Naukovyi chasopys NPU imeni M.P. Drahomanova. Sotsiolohiia. Sotsialna robota. Upravlinnia - Scientific journal of NPU named after M.P. Drahomanov. Sociology. Social work. Social pedagogy. Management, 11, 47-54 [in Ukrainian].

5. Povidaichyk, O.S. (2019). Teoriia i praktyka profesiinoi pidhotovky maibutnikh sotsialnykh pratsivnykiv do naukovo-doslidnoi diialnosti [Theory and practice of professional training of future social workers for research activities]. Doctor's thesis. Uzhhorod [in Ukrainian].

6. Leontev, A.N. (2020). Problemy razvitiia psikhiki [Mental development problems]. Moskva: Smysl [in Russian].

7. Karamushka, L.M. (2003). Psykholohiia upravlinnia [Psychology of management]. Kyiv: Milenium [in Ukrainian].

8. Stasiuk, V.V. (2014). Rozvytok motyvatsii dosiahnennia u slukhachiv yak umova efektyvnosti protsesu uchnnia [Development of motivation to achieve students as a condition for the effectiveness of the learning process]. Visnyk Natsionalnoho universytetu oborony Ukrainy Bulletin of the National University of Defense of Ukraine, 3 (40), 149-154 [in Ukrainian].

9. Mc Clelland, D.C., Atkinson, J.W. \& Clark, R.A. (1958). A scoring manual for the achievement motive. Motives in Fantasy, Action and Society, N. Y., 112-148.

10. Peterson, C. \& Seligman, M. (2004). Character strengths and virtues: A handbook and classification. Washington, DC: American Psychological Association.

11. Gardner, H. (1983). Frames of mind: The theory of multiple intelligences. Heinemann.

12. Fedorenko, A.V. (2013). Razvitie sotsialnogo intelekta budushchikh pedagogovpsikhologov v protsesse adaptatsii k uchebno-professionalnoi deiatelnosti. Avtoref. diss. kand. psikh. nauk [Development of social intelligence of future educational psychologists in the process of adaptation to educational and professional activities]. Extended abstract of candidate's thesis. Samara [in Russian].

13. Kaplunenko, Ya.Yu. (2016). Osobystisni chynnyky rozvytku sotsialnoho intelektu u fakhivtsiv sotsionomichnykh profesii [Personal factors of development of social intelligence in specialists of socionomic professions]. Candidate's thesis. Kyiv [in Ukrainian].

14. Batson, Ch.D. (1997). Self-other merging and the empathy-altruism hypothesis: Reply to Neuberg et al. Journal of Personality and Social Psychology, 73 (3), 517-522.

15. Suprun, D.M. (2018). Teoriia i praktyka profesiinoi pidhotovky psykholohiv $\mathrm{v}$ haluzi spetsialnoi osvity [Theory and practice of professional training of psychologists in the field of special education]. Doctor's thesis. Kyiv: NPU named after M.P. Drahomanov [in Ukrainian]. 